\title{
NOTÍCIAS BIBLIOGRÁFICAS
}

\section{RECENSÃO}

LULL (sicl), Ramon: Das Buch vom Heiden und den drei Weisen traduzido e editado por Theodor Pindl Stuttgart: Philipp Reclam, jun 1998, ISBN 3-15-009683-6, 306 S.

No início deste ano, contemporânea a uma edição comemorativa dos quarenta anos de existência do Institutus-Raimundus-Lullus em Freiburg i. Br., um tanto atrasada, mas nem por isso menos importante, apareceu a tradução alemã do Liber de gentili et tribus sapientibus, (em catalão Llibre del gentil e dels três savis). Duas circunstâncias tornaram importante 0 aparecimento deste livro para todos os que se interessam por Ramon Llull e pela cultura catalã. Em primeiro lugar, por ser esta não somente a primeira edição completa desta obra em alemão, que substitui a edição selecionada, muito fragmentária, de Xosé e Elisabeth Scheible ${ }^{1}$ mas, ao mesmo tempo, por ser a primeira tradução completa em língua alemã desta obra. ${ }^{2}$ Além disso, o fato de este livro aparecer numa tão conhecida editora como a de Philipp Reklam indica que o Buch vom Heiden und den drei Weisen será, pelo menos nos próximos anos, a obra de Llull pela qual os leitores alemães terão o primeiro contato com o fascinante pensamento do maiorquino. Esta obra, que representa uma importante contribuição para o discurso inter-religioso na Idade Média, presta-se verdadeiramente como introdução ao pensamento do Doctor Illuminatus e apresenta as características essenciais da análise combinatória de sua Ars, de forma altamente explícita e igualmente estética e literária. Constituem seu guia e base narrativa os diálogos de três sábios, representando as três grandes religiões, enquanto caminham por uma selva até a descoberta dum locua amoenus, magistralmente descrito, em meio do qual encontram cinco grandes árvores, em cujas folhas se acham gravadas as combinações binárias dos princípios básicos lulianos. Aqui os três sábios, e com eles o leitor, são conduzidos pela dama Inteligência, e com ajuda das árvores, na funcionalidade da análise combinatória luliana, antes de exporem racionalmente aos desconfiados pagãos a confortadora verdade salvifica da respectiva fé de cada um. Com isso o tradutor e editor Theodor Pindl, que já se distinguiu com diversos trabalhos, especialmente sobre o Breviculum, satisfaz na sua versão, com poucas exceções, ${ }^{3}$ as qualidades tanto filosóficas como literárias da obra e produz um texto

1 Ramon Lull [sicl] Buch vom Heiden ind den drei Weisen, Freiburg i. Br.: Herder, 1986. Sobre ela veja-se também a discussão de Axel Schönberger e Tilbert Stegmann no Zeitschrift für Katalanistik 1 (1988), p. 244.

2 Mesmo a excelente edição de estudo, em duas linguas da Neuen Logik de Charles Lohr (Hamburg, Felix Meiner Verlag 1985) não reproduz o texto original completo.

3 Logo nas primeiras páginas aparece a tradução de scientia intelllectualis por Geisteswissenschaft. Esta noçăo é não somente anacrônica, visto que, na maneira atual de ver, na Idade Média não se

\begin{tabular}{|l|l|l|l|l|l|}
\hline VERITAS & Porto Alegre & v. 43 & $\mathrm{n}^{\mathbf{9}} 3$ & Setembro 1998 & p. 733-782 \\
\hline
\end{tabular}


bastante legivel. No entretanto, nảo baseou sua tradução na edição crítica do texto catalão feita por Antoni Bonner, ${ }^{4}$ publicada em 1993 na série Nova edició de les obres de Ramon Llull, mas recorreu à edição latina de 172l, de Ivo Salzinger, reeditada em 1965. O que é de se admirar, pois a edição feita em Mainz por Ivo Salzinger, como é sabido, sofreu numerosas modificações no que diz respeito à ordem das frases e à escolha das palavras feitas pelo editor.

Para ajudar a leitura do texto aos não iniciados poder-se-ia desejar um maior número de notas que, num texto de quase 250 páginas, mal chegam a trinta. O mesmo se pode dizer sobre a falta de uma bibliografia introdutória e complementar, que seria de grande utilidade para a compreensão de um pensador ainda pouco conhecido na Alemanha, pelo menos nos círculos leigos. Em compensação é bastante proveitoso ler o excelente e muito pormenorizado posfácio do editor, que nos transmite não somente informação sobre a vida de Llull e seu tempo, mas também uma introdução, de fácil entendimento, sobre a sua Ars combinatoria. Nela, Theodor Pindl, partindo dos inícios da análise combinatória desenvolvidos no Buch vom Heiden und den drei Weisen, estuda esta análise até a sua forma final e completa alcançada nas últimas grandes obras de Llull. Seu posfácio termina com uma interessante perspectiva sobre a influência do pensamento luliano em Thomas Le Myésier, em Giordano Bruno, Nicolau de Cusa e Leibnitz, até a descrição do grande projeto editorial da Raymundi Llulli Opera omnia de Ivo Salzinger, nos começos do século XVIII. Termina aqui a exposição da tradição lulliana, se bem que teria sido oportuno fazer alguma breve referência ao excelente trabalho editorial desenvolvido pelo Raimundus Lullus Institutus nos nossos tempos. Possivelmente a causa que fez omitir neste posfácio a menção da pesquisa lulliana mais recente foi a modéstia (mal entendida) de Theodor Pindl - pois ele próprio participou da edição do Raymundi Lulli Opera Latina.

Para terminar, merece também referência a rica ilustração, apresentada em sua totalidade segundo o estilo de próprio Llull. O posfácio inclui, além das figuras A e T da Ars Brevis, também quatro das magníficas miniaturas do Breviculum com cenas chave da vida de Llull. É de se agradecer, especialmente à editora, que, contrariando as suas próprias normas editoriais, depois de aigumas hesitações iniciais, decidisse introduzir as ilustrações das cinco árvores no texto.

Em resumo, trata-se de um livro estimulante para todos os que se ocupam, ou querem se ocupar, da filosofia e literatura medievais (catalãs). Esperamos que, com a presente tradução, uma tradição acadêmica alemã interessada em Liull, de mais de cem anos de antigüidade, alcance finalmente larga publicidade.

Alexander Fidora, da Johann Wolfgang Goethe-Universität, Frankfurt, Alemanha. Trad. de Sivar Hoeppner Ferreira

diferenciavam Geisteswissenschaft e Naturwissenschaft, além de contradizer o entendimento de Llull, segundo o qual sua ciência (Wissenschaft) representava uma protociência (Protowissenschaft) e, em consequiência, apresentava todas as diferenciações como diversos ramos da ciência.

4 Ramon Llull: Libre del gentil e dels tres savis, Antoni Boni (ed.), Palma: Patronat Ramon Llull, 1993. 